\title{
INDIRECT ACTIVISM: Graffiti and Political Possibility in Athens, Greece
}

\author{
OTHON ALEXANDRAKIS \\ York University \\ (D) http: / / orcid.org/0000-0003-1993-907X
}

When considering resistance or political responsiveness to neoliberal governmentality, researchers often focus on efforts that push directly against the compromise of well-being, precaritization, and abjection. In this essay, however, I consider another mode of responsiveness, attuned more directly to the politics of neoliberal regulation, especially the effacement of agonism and critique that underpins advanced capitalist power. By examining the formation of resistant subjectivities among a group of young graffiti writers in Athens and the activities they undertake in response to changes that threaten to restrict or undermine the social imprint they might have on everyday life, I sketch an understanding of resistance and the making of political possibility in terms of indirect connections between diverse groups, multiple interests, fears, and the reverberations these produce across political realms and scales.

A case in point: Thomas reached up, shook the can of spray paint in his hand sharply, and released a blast of purple. He put the can down, grabbed black, and reached up the wall again. Thomas and his friends, Aris and Tassos, were working on a complex mural at the entrance to an alleyway near a busy intersection in Athens. I had come along to observe. My interlocutors were painting the side of an old apartment low-rise - one of many buildings hastily repaired in the lead-up to the 2004 Olympic Games that were now, a mere four years later, crumbling once again. Thomas used the handle of a screwdriver to enlarge a 
section of broken plaster, which he then shaded with black and gray. Aris contributed a figure of a municipal worker texting on a phone with one hand and blindly hammering on the wall with the other. Tassos painted an ornate frame around the piece. He explained: "This is something different. People have to think."

Indeed, as I watched the frame take shape, I began to think about the piece's relationship to its context: a run-down neighborhood in which two of every three storefronts were shuttered, where dumpsters were surrounded by opened garbage bags picked clean of salvageable contents, where local residents complained about exhaustion and the mounting uncertainties in their lives. The piece seemed unnecessary to me, and perhaps even a touch cruel in this neighborhood; Thomas and his friends had further broken a crumbling wall to put up a piece that did little more than evoke a familiar narrative of injury caused by state ineptitude. Then it struck me that the graffiti crew had offered a mocking view of the state, while telling a local story in a way that prompted viewers to reflect on the situation. Taken this way, the graffiti was as much about the troubling familiarity of broken plaster on the ground as it was about the little absent-minded figure in the frame.

This scene took place in the months leading up to 2010, when the Greek state declared sovereign debt crisis and began to implement an aggressive austerity program in exchange for economic aid from the European Union (EU), the European Central Bank (ECB), and the International Monetary Fund (IMF). During the coming years, successive governments dismantled public services and oversaw a series of salary and pension reductions, increased taxes, and layoffs that resulted in sudden mass impoverishment. The Greek middle class was devastated and the lower class came to struggle further, while the so-called reforms protected financial institutions. This was also a period in which the Athenian cityscape became covered with graffiti. The usual tags and anarchist symbols (the encircled "A") proliferated, but commissioned works and other, more skillfully rendered murals and pieces put up by independent graffiti writers and crews also increased. Among these latter works a new form of graffiti emerged, one that expressed a critique of neoliberal governmentality but also engaged with such troubling trends as increasing violence against migrants and other groups, working for little to no wages at barely viable businesses, and the abandoning of the elderly. In other words, this graffiti communicated a demand for a better life while holding a mirror to the mainstream public. Here I consider this form of graffiti-a public manifestation of dissent and reflection - as one mode of political response to the 
material and symbolic violence of what is arguably among the most coercive exercises of neoliberal governmentality, at least in the developed regions of the world. It constitutes a response distinctive of, if not confined to, individuals on the periphery of the social mainstream. During the past six years, it has become part of a thriving ecology of resistance that also includes traditional organized protests, experimental solidarity movements, and everyday acts of camaraderie. Even as other champions of resistance express dissent directly or offer disruptive alternatives to neoliberal regulation, the artists of the graffiti on which I focus encourage critique and agonism even as they seek to shore up the social fabric that precaritization threatens to undo.

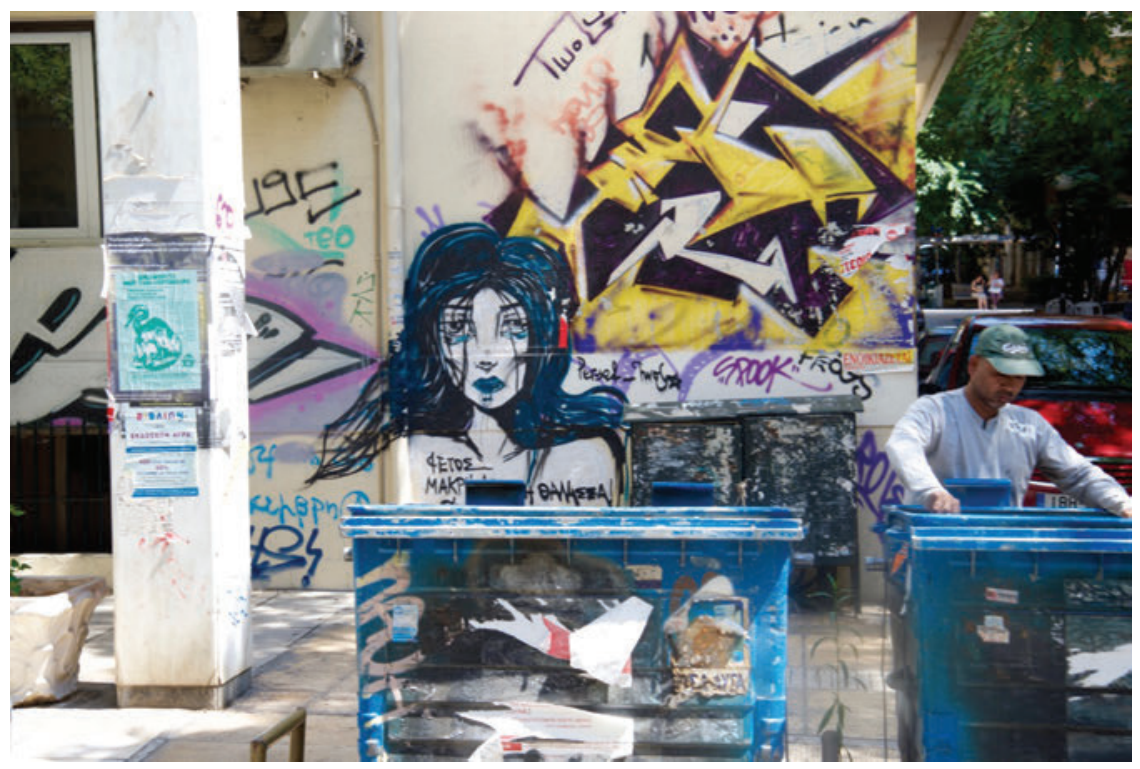

Figure 1. A young migrant man digs through an open garbage bin. The graffiti behind him depicts a drug-addicted woman with sunken eyes and cheeks and blood flowing from her lips. The caption (mostly obscured) reads: "This year, stay far from the sea! It will be a difficult year. Seal lips." This piece alludes to the arrival of migrants by sea, and was described by one resident as a comment on Greece's multiple "moral crises."

Photo by Othon Alexandrakis.

Tracing the activities of a group of three graffiti artists in Athens, both before and during the years of the crisis, this article analyzes the role of street art as a mode of political resistance and as an illumination of, or at least the provocation to consider concrete alternatives to, the politico-economic present. Addressing the fear of abjection and the experience of existing at the social margins as a stimulus to critical agency, I consider the graffiti my interlocutors write as indirect 
activism. Put simply, it is the manifestation of a mode of resistance whose critical agents attempt to bring about their ambitions and visions by activating other groups to undertake resistance of their own. My interlocutors aimed to preserve a desirable state of difference from the social mainstream, even as they sought to encourage the mainstream to resist the forces of precaritization that threatened to reduce all middle- and lower-class Athenians to individuated, economized, and thus disposable subjects. None of the crew thought that his graffiti directly related to collective action on the ground (cf. Graeber 2009; Juris 2008). Rather, the sense of possibility I trace in this article has to do with the writers' conviction that graffiti sustain the potential to bolster critical reasoning and thereby lessen the capacity of neoliberal governmentality to manufacture consent to policies that worsen their lives.

I begin in the 1990s and with the intensification of generational conflict between my interlocutors and their parents, which accompanied the slow collapse of Greece's economy at the time. This conflict, combined with their political disenfranchisement and the closing off of a desired future, intensified among my interlocutors a sense of their isolation and abandonment on multiple fronts. As the neoliberal reform agenda began to change Athenian lives in 2010, my interlocutors began to fear that they were, once again, being abandoned. This time, however, they understood abandonment as an effect of their becoming integrated into an economized social mainstream - a threat they articulated in terms of becoming ordinary (kanonikós) or lost in the crowd (omalós). In response to these fears, they undertook a campaign of graffiti writing. With this intervention they did not seek to contextualize what was happening, plot solutions, or place blame (Knight 2015; Theodossopoulos 2013). Rather, they wrote graffiti to awaken the broader mainstream population to what they understood as the normative forces structuring the process of becoming precarious.

I conducted fieldwork for this project on and off between 2007 (when I was doing research for my dissertation) and 2015. I have changed the names of my interlocutors in this article and avoided references to the exact locations within and around Athens where these individuals live and write graffiti. In addition, except for the final image in this article, the graffiti that appears here is not the work of my interlocutors. At the request of my interlocutors I have not included their graffiti, since doing so would expose their identity within certain circles. 


\section{CRISIS AND CRITIQUE}

Thinking with Janet Roitman (2014) that crisis is an apparatus of power and knowledge, I want to offer an approach to understanding the emergence of critical subjectivities and political responsiveness among young Athenian graffiti writers. Roitman explains that one of the normative impulses of neoliberal regimes is to depoliticize crisis, that is, to efface agonism, critique, and ultimately, dissent. Indeed, in 2010 the Greek state deployed a crisis narrative along with neoliberal austerity policy, effectively reducing political discourse to concerns with economic management and focusing political action on safeguarding the pervasive functions of the market. Yet as Athenians began to suffer austerity-driven injuries such as poverty, growing shame, and deepening demoralization, innovative if sometimes unconventional resistance actions such as alternative economies, solidarity collectives, and barter networks (Rakopoulos 2014) began to proliferate. Far from effecting a total inactivation and depletion of agency, sites of intense precaritization also became sites of mobilization and the politicization of shared suffering (Roitman 2014, 12).

My interlocutors were also motivated to act as precaritization began to change their lives. The action they came to pursue, however, had less to do with the mobilization of shared suffering and more with the fear of becoming interpolated into a mainstream of suffering others: rather than collectivize, they sought to maintain what they felt was good in their lives. Michel Foucault's (1997) thinking on critique, specifically his emphasis on the subject's own critical agency in constituting her or his subjectivity through acts of resistance, provides a useful framework as we examine my interlocutors' perspectives and eventual actions in response to precaritization. In a 1978 lecture at the French Society of Philosophy, Foucault argued that the norms governing knowledge, morality (legality), and aesthetic experience (pleasure and desire) are transgressible by subjects who experience crisis within the epistemological field in which they live. These subjects - individuals whose lives have become disorganized or unintelligible or who, we might say, are unable to produce meaningful explanations based on established truths - find themselves in a position (often an urgent one) to critique, to ask, as Foucault suggests, not whether a situation is good or bad, but why evaluation has failed. The experience of exceeding the limits of the epistemological horizon within which normative practice is formed may put the subject in a position of self-formation that stands in relation to the normative, rather than being obedient to it. Crisis exposes the limits of the normative (see also Roitman 2014, 65-66). 
Individuals faced with crises may become authors of themselves - they might selfauthor — at, beyond, and relative to these limits.

Judith Butler helps us connect Foucault's thoughts on critique and politics to resistance and to the present case more directly. Butler $(2002,222)$ explains that "critique begins with the presumption of governmentalization and then with its failure to totalize the subject it seeks to know and to subjugate." Questioning norms, as part of an ongoing project of the definition of the self that exceeds the state's capacity to totalize subjects, despite expectations to the contrary, makes possible a transgressive "desubjugation." The ways in which subjects undo themselves in the process of desubjugation yields critical agency beyond the normative violence of subjection itself. This project may give root to counternormativities (Butler 2002). Among my informants, critical agency was activated by an experience of desubjugation effected by the undoing of the normative principles within which they experienced and understood their abjection.

By late 2010, my interlocutors were increasingly troubled by a growing public sentiment that graffiti writing - the creative and social practice through which they performed and maintained the otherness at the heart of their understanding of themselves — was both normal and justified (cf. Jusionyte 2013). Among the people they encountered, graffiti was becoming a natural part of the changing cityscape, part of the process of austerity-driven decline and renewal, echoing government narratives about the course of the crisis and the benefits of reform policies. The media depicted graffiti writers as ordinary young people. Even the moral language around graffiti shifted from the negative "graffiti as vandalism" to the more neutral "graffiti as a means of expression." Sensing what they understood as their interpellation into the normative construal of the crisis, the group took action against the slow-motion undoing of the social and moral sites that provided their lives with stability and meaningful direction. Specifically, they took action by writing graffiti that exposed the processes of precaritization that were changing everyday lives and popular perceptions of graffiti.

Between December 2010 and the time I concluded fieldwork for this project in 2015, my interlocutors changed the way they talked about graffiti writing, from committing acts of defiance to putting up guerilla social commentary that "plagiarized" (to use Aris's word) state logics and caricatured their effects. This was not a situation in which peripherally engaged, disappointed (Greenberg 2014), or exhausted (Berardi 2012) subjects became politically active or otherwise involved. Rather, as they began to fear the negative possibility of their becoming mainstream, my interlocutors engaged with the political sphere indirectly, from 
one step away, exposing the totalizing normativities that were impoverishing Athenian lives and setting the conditions for social abandonment.

I use indirect to describe Aris's and his friends' interventions to flag an important difference between their actions and other forms of activism, including so-called new activism (Juris 2012). We can understand indirect activism as a politics that puts identity into question. Specifically, unlike collective political action grounded in identitarian forms, indirect activism does not appeal to a shared sense of being or having in common. Instead, indirect activists communicate across exclusionary forms by which people demarcate established communities to bring about broad collective responsiveness. This responsiveness offers a vision of social cohesiveness that poses a challenge to established identities while demanding change.

Thinking with Gilles Deleuze and Félix Guattari (1986), we might consider my interlocutors' intervention in terms of a minor literature: a space within the mainstream of experimentation that exceeds canonical models or normative expression. Writers of minor literature are engaged in the invention of becoming other, or the invention of a "people to come" (Deleuze 1997, 90). They effect variations from the mainstream. In the case at hand, my interlocutors create pictographic messages that place them one step away, or in a position that is exceptional to, the normative violence to which the neoliberal governmentality subjects the mainstream population. The active self-authoring and subversion of the normative in the production of an intervention is immediately social and political. Indirect activism is thus a politics built not on common identity but on interconnectedness.

\section{GRAFFITI WRITING AND BECOMING OTHER}

My three interlocutors grew up in Kifissia, an upper-middle-class suburb of Athens, during the 1990s. Their generation missed the German occupation during World War II, the civil war (1946-1949), the military junta (1967-1974), and periods of political violence during the late 1970s and 1980s. Instead, they enjoyed a relatively long period of political and economic stability and benefited from the increased buying power that came with Greece's adoption of the euro in 2001.

Aris lived with his parents and brother in a large house near a small park on a quiet street. His father was a steadfast supporter of the conservative party New Democracy and held a well-paying government job, which he had secured through the influence of his uncle; his father never hid the fact that clientelism made this position possible (Mouzelis 1978; Sotiropoulos 2004). Thomas's father 
also held a government job, which he had secured through a family friend. Thomas lived with his parents and sister in a large apartment down the street from Tassos. Tassos lived with his mother in a small apartment. His mother worked at a nearby supermarket. The two of them lived off her modest salary and the money Tassos's grandmother would save for them from her pension. The three boys went to school together and their families knew each other. The adults in my interlocutors' lives would become nostalgic for this early period as crisis and austerity set in, the everyday became messy, and their futures became increasingly uncertain.

As my interlocutors moved into their teenage years, they began to spend more and more time with their paréa (a local social category describing close groups of friends and/or kin; see Cowan 1990; Kirtsoglou 2004; Papataxiarchis 1991), outside of the local community. The boys' parents did not approve of this behavior or of their friends. Their parents also began to complain about how they were spending money. The fathers put their sons on strict allowances and often questioned them about their purchases. Both Aris and Thomas accused their parents of trying to control them by restricting and monitoring their spending. Tassos's mother fell ill and stopped giving him money altogether. He blamed both his mother and her employer for her failing health and, generally, for their lack of money. His mother would in turn accuse him of caring more for his paréa than for her.

When tensions exploded into fights, Aris and Thomas would point to their fathers' employment, questioning their morality to undercut their authority. As Aris put it:

My father would tell me to work harder at school or to stop spending time with my friends. Why? He and the rest of his generation were just handed jobs - my father failed to complete high school and he oversees an entire department within the government! It's ridiculous!

In his last year of high school, Aris hardly spoke to his father, and Thomas had an actual physical altercation with his own father. Tassos, however, fought less frequently with his mother during this period. According to him:

After years of fighting I began to pity her. She worked very hard for very little money at a job that was obviously killing her, and she still defended her boss. She was brainwashed! She wasn't a free, rational person! I couldn't take the things she said seriously. 
For my three interlocutors, recurring episodes of conflict in the home and finding solace among friends informed their thinking about morality, authority, and a desirable life. The group began to imagine a future without the socioeconomic entanglements and consumerism they saw as definitive of an older generation caught up in the post-1981 national political work of inventing a European middle class. Instead, my interlocutors wanted a life in which they could be free to make choices and do the things they liked: a life they would flirt with on the streets and among their paréa. In so doing, the group began to demarcate a positive social field of practice.

Aris's father did not see the situation this way. He began to call his son aliti - a negative term referring to a "punk" or a homeless person, generally, someone offensive. Aris accepted the label. In fact, his friends came to also selfidentify as alites and began performing alitiés, that is, doing things that asserted their independence from the various milieus and specific structures claimed or shaped by limiting authority figures: an entanglement of parents, police, government agents, and big business. It was around this time that my interlocutors began to play with spray paint.

The group became invested in graffiti writing as its members began to understand the social life behind the pieces they admired and as they came to develop a style of their own. They also began to see graffiti as more than just a medium through which to assert their independence from authority. My interlocutors explained that watching graffiti be put up, sprayed over, modified, and fade gave subtext to Athens. They began to read the claiming of space and working to earn respect on walls (see figures 2 and 3) as a drama played out between individuals who would act according to their desires and by developing skills against the various figures (both within the graffiti scene and beyond it) seeking to limit them.

They began also to read an unfolding narrative in and of particular streets and neighborhoods (see figure 4) written by individuals and groups acting free of convention and expectation. As their lives worsened at home, graffiti became increasingly legible to the group as a nonmainstream discursive site where participants could express themselves, be acknowledged, and contribute to a meaningful dialogue. They took up writing as a group rather than individually, as Thomas explained, "for greater protection against police, and to speak with one, louder voice." The strong bonds graffiti writing engendered among the friends came to inform an affective geography connecting what we might consider the 


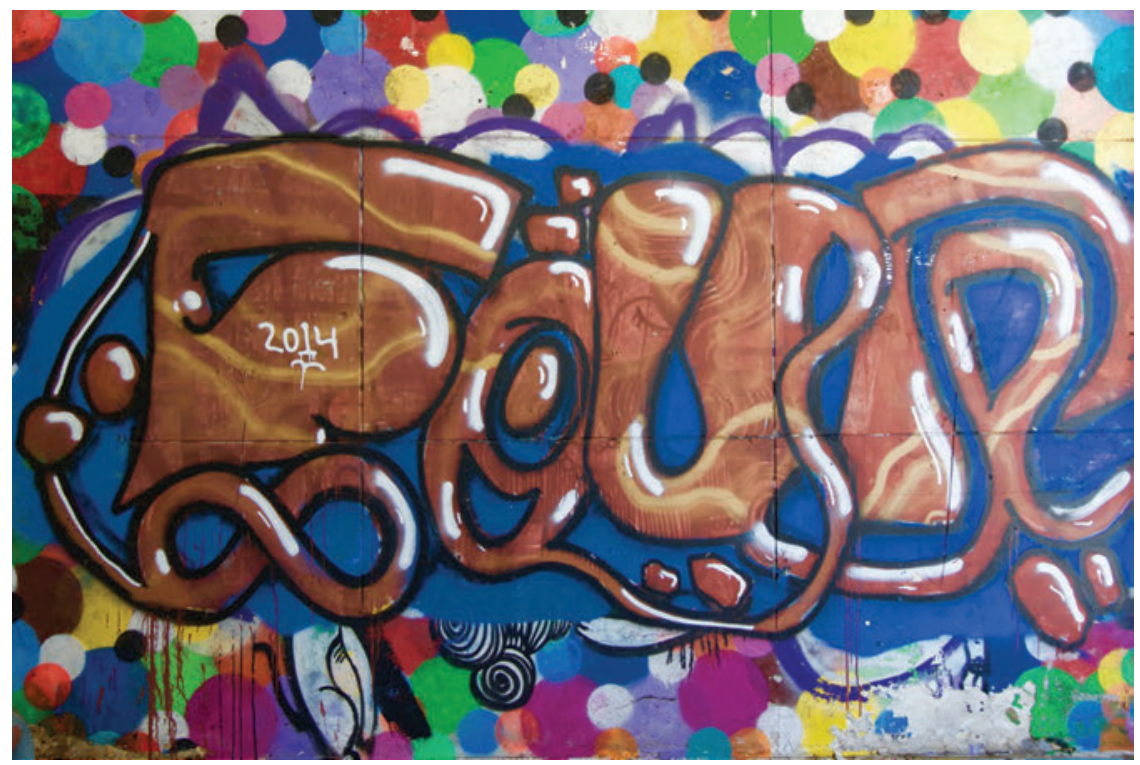

Figure 2. An example of layered graffiti. There are at least four different pieces in this photo. New pieces rarely obscure the graffiti underneath completely, allowing viewers to trace a history of covering. Space on walls is limited in Athens, and only the works of respected writers and crews remain uncovered for any length of time. Photo by Othon Alexandrakis.

interiority of my interlocutors' self-authoring with the streets of Athens (NavaroYashin 2012).

With time, however, my interlocutors focused less on trying to win respect and space on walls, and although they continued to follow local narratives, the impulse to contribute to the conversation waned. In part, this change had to do with the group's suspicion of the state's growing interest in highlighting graffiti as a cultural form in the lead-up to the 2004 Olympics. The group had become wary of the growing number of graffiti festivals and commissioned works, which they took as signs of the institutionalization of graffiti. As some of the more talented graffiti writers in their area began to participate in festivals and agreed to take commissions, my interlocutors feared that the subtext of Athens would become "thinner," to use Aris's word: writing would become more random, and less responsive and aware. This thinning signaled to my interlocutors that something larger was changing in the graffiti scene, that the free discursive quality that had defined it was undergoing erosion (cf. Císař and Koubek 2012).

Between 2002 and 2005 the group began developing the style and quality of their graffiti. They found this move empowering: not only were they freer to experiment with graffiti as a form; by doing graffiti differently from others (who 


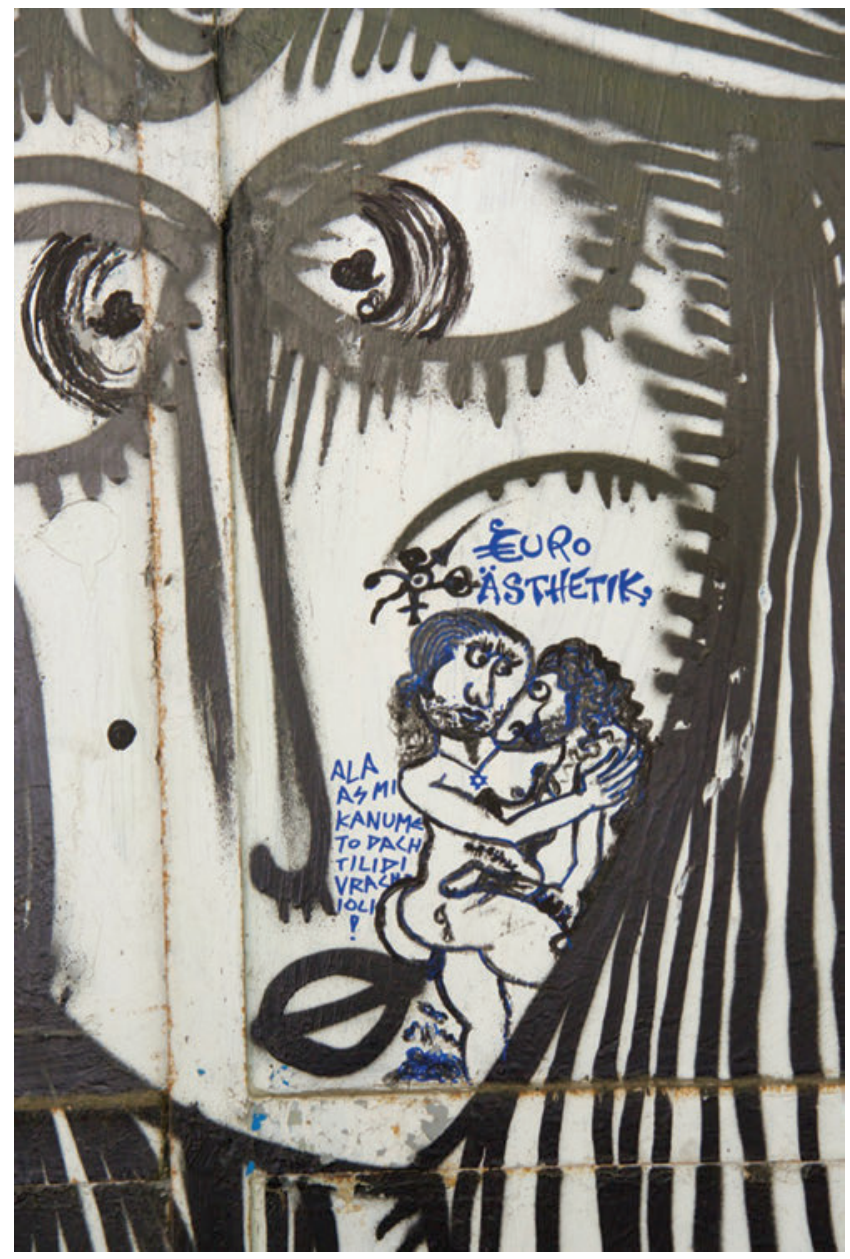

Figure 3. Here, a work by Sonke was modified with two small figures and text. By modifying

Sonke's piece with writing of lesser quality, the modifiers have made the entire work vulnerable to covering by other, less respected artists. This kind of covering, or modifying, is considered disrespectful among most Athenian graffiti writers. Photo by Othon Alexandrakis.

they felt were now jockeying for recognition from the mainstream), they also developed a sense of critical perspective on the form itself. This marked an important formative period for my interlocutors. According to Tassos:

I think we all realized that graffiti is a way of saying "fuck off," of saying "I love you," "wake up, moron" — and absolutely nothing at all. We used it to express anxiety, arrogance, passion, destructiveness, and, and, and . . . our graff became us once again. 


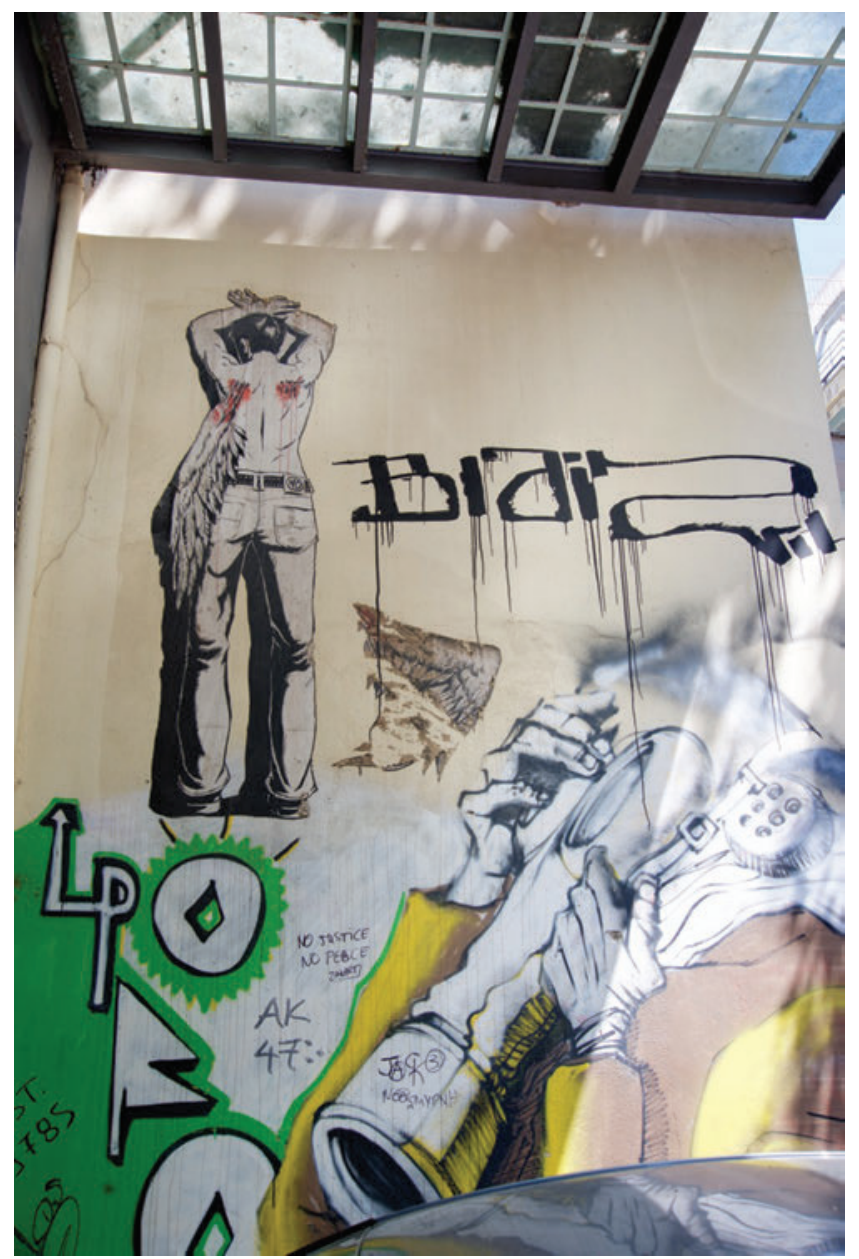

Figure 4. The different pieces on this wall, located in the Exarcheia neighborhood, tell a local story of ruined futures and political dissent. The two largest works (the top one of which was created by renowned artist WD) were put up at different times. The small tag in the middle of the wall, which reads "No Justice, No Peace," captures the spirit of this small cluster of works. Photo by Othon Alexandrakis.

My informants' sense of being alites changed from an identity defined as "being bad" to being outside the social mainstream, and now to indexing an outside view looking in. This positionality came to define their sense of social selfhood, which would in turn inform their alterity.

By 2005, Aris had moved downtown to attend university. Thomas moved in with him, while Tassos remained in their old neighborhood, living at home (he did not pursue further schooling, although he registered at a local technical college to avoid military service). They all met in the city regularly to write graffiti. 
Rather than stay within one neighborhood, they adopted a new territory. Asked how they came to determine where they would write within this territory, Aris explained it was about a feeling: certain places felt more open to their writing, while other places did not; some places felt like they needed alitiés, while others did not. A sentiment of interventionism in this reply foreshadowed the more direct interventions they would undertake post-2010. Aris explained that the quality of the surface, what it looked and felt like, related to the area. The constellation of surface, area, and sketch (graffiti plan) would either work or not. Thus their territory was informed by the crew's "active sensing" (Feld and Basso 1996, 7) of local stories (istories: see Herzfeld 1987, 41-46) that captured fragments of social experience and intimate social knowledge; local power dynamics read in terms of visual silences (lack of graffiti); the style and quality of architecture and urban planning; the limits of their artistic skills; and the group's vision for their work.

My interlocutors' thinking around what it meant to be alites consolidated during this period. They found themselves completely dispossessed of a predictable future and typical kin relations, disillusioned with the graffiti scene, but fully engaged and committed to experimenting with writing graffiti that communicated critique. The group members began to refer to themselves as a crew-a designation common among graffiti writers internationally but which, in this case, also marks a more intimate subset of the paréa, rather than a distinct social or corporate entity. They developed a new tag for themselves and began putting it up with new pieces they wrote. They used the tag for the first time with a piece that captured their outsider perspective and relation to the social space in which they lived and wrote. The site was typical of precrisis Athens: an old single-family home, uninhabited due to competing inheritance claims, had been sold off to a developer who-according to locals - had bribed officials to approve the construction of a low-rise apartment building that would cover every square inch of the once green property. Citing a need to respond to the power the developers exercised, the sense of entitlement with which they seemed to operate, and to the greed they perceived at the root of the legal dispute that had led to the situation in the first place, the crew came up with a plan.

On a late Saturday night, Aris, Tassos, and Thomas entered what would become the front foyer of the building and painstakingly shifted a stack of bricks that had been piled against a wall facing the front entrance. They proceeded to paint a large image of a woman dressed only in fishnet stockings, holding a cigarette and surrounded by cloudy euro symbols. The crew then painted euro 
notes on each brick before replacing them in front of the image of the woman in such a way as to leave only her head visible. It took my interlocutors more than six hours to complete this piece. The next week, as the bricks were used up, workers slowly uncovered the naked woman. Tassos chuckled as he explained the friends' thinking:

There's a hooker in all of us, but money brings her out more in some people than in others. You can figure out the rest - it's all about motivation and violation! We had such a laugh with this one . . . we still laugh whenever we see someone go in through those doors and is greeted by the hooker under the paint!

The social valence the crew occupied, the valence of difference or otherness with which the alites self-identified and which set them apart from the social mainstream and other writers, was an effect of the outsider's perspective on normative (bourgeois) values that they cultivated, the sites and terms of their selfauthoring, and the histories of abjection and coping they shared. Their self-identification as distinguishable from some mainstream public preceded, I will argue, the emergence among them of a kind of reflexivity we might associate with a subject who exceeds social regulation, thus becoming open to (and capable of) a relation to alterity (Butler and Athanasiou 2013, 69-70). In other words, the crew's understanding of themselves as somehow beyond the formations of power that enacted subjects - and as distinguishable from the subjects this power enacted - both grounded and capacitated their becoming other.

It is tempting to revert to stereotypes when describing my interlocutors at this point in their lives. Local non-academic commentators were discussing the idea of a "wasted youth" or "lost children" (hamena pedia) of Athens. ${ }^{1}$ The media portrayed this population as made up of young people of socioeconomically diverse backgrounds who had little to no interest in politics of any stripe, who were not preoccupied with their financial future, were minimally invested in the lives of anyone beyond their close kin relations and friends, and who expressed general antiauthority attitudes. These individuals were often depicted as living on the edge of the kind of anomie described by Émile Durkheim (1951), in a state of being disconnected (Allison 2009) from their fellow citizens and even from their broader peer groups. They were bored (Mains 2007). They did drugs. They vandalized property. They wrote graffiti. Analysts and politicians engaging in crisis talk typically vilified the lost youth. In casual conversations at cafés and in living rooms throughout the city, citizens lamented and condemned this population, 
deeming it both a shame (dropi) and shameful (cf. Herzfeld 1985): a population trapped in a state of political impotence and depressive hedonia, as Mark Fisher (2009) would put it. Some of my contacts at the time went so far as to suggest that becoming lost was an innate risk particular to the Greek character: an embedded, magnetic possibility that must be resisted if one is to participate in the modern European political economy (see Herzfeld 2005). Clearly, that characterization manifests several problems, not the least of which is the romanticization of individuals like my interlocutors either as wayward outsiders without a cause or as passionate Greeks unable to resist their baser, unmodern impulses.

It is also tempting to locate my interlocutors at this point in their lives within particular Greek political trajectories. For example, as with other Greek youth who wrote graffiti, who appeared in public wearing hoodies, and who appeared to be delinquents, my interlocutors could be placed within a complex political genealogy of students who undertook what Christos Giovanopoulos and Dimitris Dalakoglou $(2011$, 93) have described as the continuous breaking of Greek political structures following the end of the military dictatorship in 1974 (see also Panourgiá 2010). Indeed, and for what it is worth, my interlocutors' actions fit within the broad spectrum of possible expressions of disaffection and anger this population experienced and made public. I say "for what it is worth," however, because the crew rejected even this broad characterization. According to my interlocutors, they were not anarchists, antifascists, or antiauthoritarians (antiexousiastes), not urban guerrillas of any kind or hooligans. They may indeed have contributed to a history of politically disruptive youth behavior, but suggesting this to them elicited scoffs and the accusation from Thomas that "anyone who thinks this does not understand what we write and why we write it."

By the mid-2000s the crew rejected standard identifiers available to Athenian youth searching for an identity, including the various versions of "lost youth" or "radical youth." Rather, they described themselves as "graff artists." Indeed, graffiti writing came up again and again in conversation as a "commitment," "inspiration," “obsession," an "escape," and ultimately a "way of life." Notably, it did not come up in terms of a community. The members of the crew shared a sense of being other, even from their fellow graffiti writers. The process of self-determination Aris, Thomas, and Tassos engaged in fostered among them a sense of belonging to society, albeit as outsiders, rather than a sense of having-in-common with other graffiti writers. In other words, their sense of belonging was based on the actualities (and contingencies) of their association as active and willing coproducers of their own otherness to the mainstream. Among my interlocutors, this coprod- 
uced otherness was observable in the world; it was grounded on the rhetorical terrain and valuations they produced and reproduced over and again in graffiti and by way of graffiti writing, and each member of the crew felt it. This feeling provided the skin of the crew qua (politically distinguishable micro-) collective (see Ahmed 2004). This feeling indexed their otherness to the mainstream while providing the internal terrain that signaled their collective productions uniqueif not necessarily in form, then in meaning. This feeling was also found at the heart of their advocacy, as I show in the following section.

\section{WRITING ALÍTICO}

I met Aris at a café near Omonia Square in Athens on a warm morning in the late summer of 2011. Athenians were beginning to experience the effects of the troika austerity measures, but the café — a notably pricey establishment, my interlocutor suggested — was bustling. Having just told me a funny story about his adventures with the crew the night before, Aris stared down at his nearly empty glass of whiskey (his attempt at fending off a hangover) and said in a surprisingly matter-of-fact tone, "I fuck life. I ride in stolen cars, smoke heavy cigarettes, ${ }^{2}$ and work hard at getting laid, like most people my age. But I also write graffiti.”

Breaking the silence that followed Aris's statement, a waitress came by with a second round of drinks, served with the bill rolled up in a small shot glass, as is the convention in Athens. I reached for my wallet, but Aris was quicker with his, folding a €20 note and placing it in the glass before I had a chance to do the same. He explained, "This cash is from my father. He doesn't really care what I do or where I go anymore-I just take money from his wallet whenever I go home. He knows I do this, but he doesn't say anything. He has his problems and I have mine." Aris's father's problems had recently changed. As with many other Athenians facing uncertain futures but holding on to the last gasps of their preausterity lifestyles - like many people at the café, I suspected-Aris's father had received notice of termination but was living on as he had before. The creep of precarity, however, was beginning to produce new silences in the household, the turning of blind eyes, awkward smiles, and other everyday changes that hinted at the situation to come (Stewart 2007).

Moving away from home provided Aris, as it did Thomas, distance from and perspective on his still strained, if changing relationship with his father. Tassos was gaining new perspective as well. His mother's failing health - a combination of a worsening repetitive strain injury and barely controlled diabetes - meant the 
time he now spent at home was taken up with little other than helping her through her mornings and evenings so she could continue to work, lest she be fired. Tassos came to observe a change in what we might call, following Sianne Ngai (2004, 28-29), the tone of his relationship with his parent as she made requests of him, but was no longer interested in his life or willing to argue. This signaled to Tassos that a change was underway: his mother was seeing things differently. She was seeing him differently. All three of my interlocutors noted the turning away of their parents from an understood promise to support their well-being. So all three of the young men came to be preoccupied with figuring neoliberal governmentality and its effects on individuals. This marked a return, once again, to a concern with authority and how authority shapes lives. In this case, their concern was with how authority incited or coerced individuals to govern themselves.

By 2011, my interlocutors had become alarmed not only because the crisis moment had effected a change in their parents and, ultimately, in their relationships with their parents, but because they saw this change as symptomatic of a broader social transformation. The crew had noticed an explosion of graffiti across Athens, which they understood as evidence that growing numbers of individuals were responding to alienation and abandonment by a state that has historically promised its citizens the maintenance of their welfare from birth to death. Yet this broader transformation did not appear alarming until one morning, in the early months of 2011, when the crew was caught painting a large toilet on the shutters of a luxury furniture store beside a bank (part of a larger design connecting the two businesses). Rather than becoming angry, Tassos explained, the owner of the business put his arm around him and said something to the effect of: "Finally, you've made me part of the neighborhood. It's about time someone put graffiti here." Tassos recalled this interaction with a shudder: "It was like we did him a favor . . . like we did a commission for free." He explained that graffiti had become so common in the city - quite literally covering almost every surface of Athens - that it was also becoming ordinary. My interlocutors feared that as the crisis intensified, or rather, as neoliberal governmentality was consolidated and impoverishment spread, the crew was becoming mainstreamed and interchangeable with the masses of others who were being abandoned (an unfortunate agglomeration that included novice graffiti writers as much as their parents).

Indeed, in this case, fear registered an awareness of a real threat to the integrity, as it were, of the writing group (Ahmed 2004; Massumi 2010): to the dissolution of the social forms, valuations, and even rhetorical base from where it emerged. Accordingly, the issue for my interlocutors was not with some "high- 
minded concern" (as Thomas put it) over public well-being or the plight of vulnerable populations; rather, it concerned the preservation of the crew's own position of otherness within the social milieu, of its own mattering. The threat of becoming ordinary, of becoming one of the crowd of individuated, increasingly competitive, and necessarily self-reliant Athenians, activated among them a kind of reflexivity that enabled my interlocutors to sustain themselves despite forces that would have changed them, and so preserved and kept open a relation to alterity (Butler and Athanasiou 2013, 69).

Seeing the change in their parents and realizing that it was symptomatic of a threatening emergent present stirred among my interlocutors a desire to respond. Inspired by the work of famous disruptive street artists like Banksy and Shepard Fairey, and by talented local artists like Dan, WD, ${ }^{3}$ and Aptemhs, the crew began to experiment with a mix of stencils, tags, and witty captions. According to Aris, the mixed style gave their graffiti a "cleaner look," helping it stand out. The items they created were lighthearted and immediately understandable. Their intended audience was regular people, quite literally, on the street. They wanted to challenge viewers to see themselves, their surroundings, and their situation differently - in other words, to effect a progressive deterritorialization of an emerging ordinariness by offering a view of the social self from the perspective of the crew (cf. Sweeney 2011). Aris referred to this perspective as alítico.

Cedar Lewisohn (2008) explains that street art constitutes a subgenre of graffiti that challenges one's experience of urban space. Street artists use stencils, murals, and even one-liners to provide critical social and political commentary. Here, street art challenges the normative "regime of visibility" (Rancière 2004, 22) ultimately calling into question the underlying formations of space, variously construed. Alítico graffiti can be considered a style of street art. By depicting the effects of governing through crisis management, my interlocutors created surfaces that challenged the normative principles coming to enact neoliberal subjects.

The crew developed careful pieces depicting precarity in the form of hunger, displacement, job insecurity, illness, and so on as normal: a pastoral scene of an emaciated farmer sitting on a new Mercedes Benz, watching his equally emaciated goats (located across from a bank); a middle-aged man driving a moped with his feet and arms bound in a body cast, setting off to deliver a pizza (on a wall surrounding a hospital); a figure of a young woman bent into a dumpster, Nietzsche in her pocket (near a university building). Aris and Tassos characterized this form of graffiti as "the aggressive transformation of the world into a scene," which 


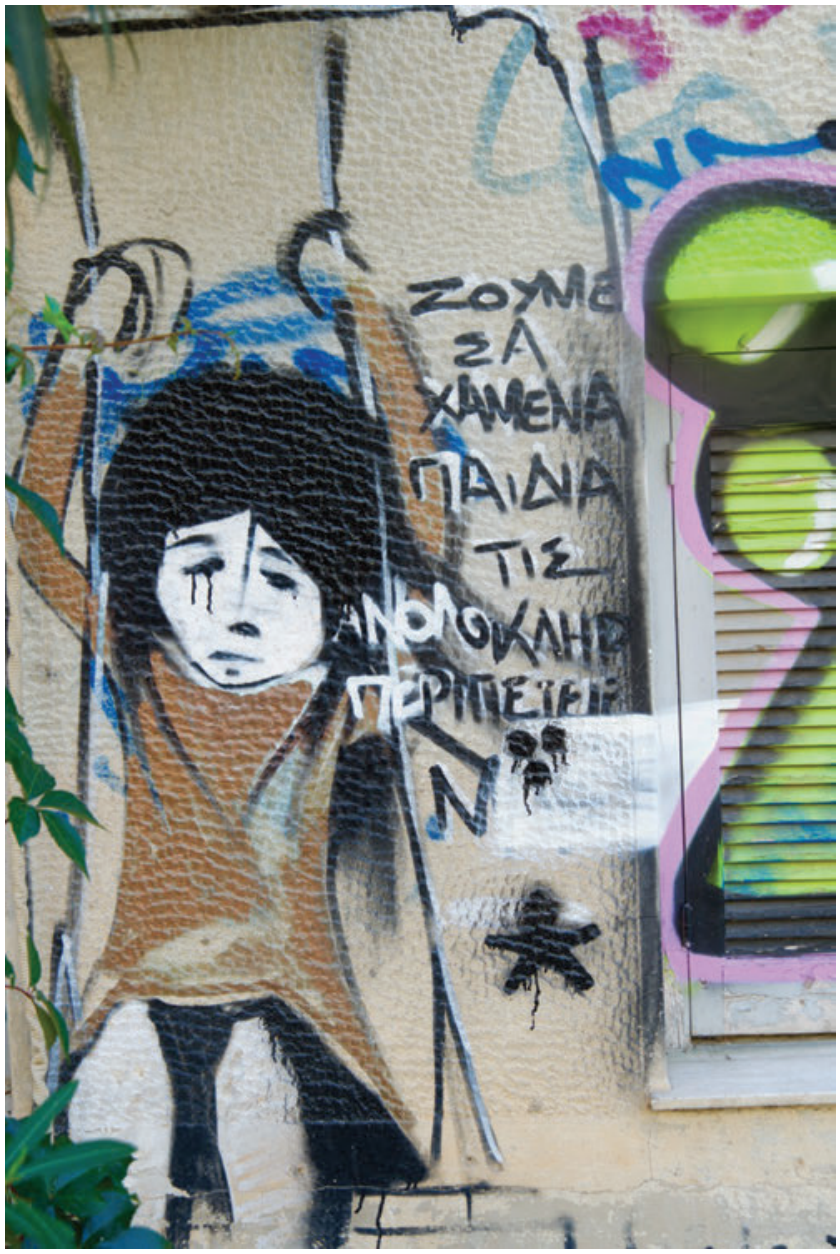

Figure 5. This piece, made by a combination of stenciling and freehand painting, was put up on the wall of a day care center. The (misspelled) caption is meant to read: "We live like lost children of the incomplete adventure." Photo by Othon Alexandrakis.

calls into question "the new relations in the situation." Their graffiti writing became a critical engagement with, and push against, the aspects of the emergent normative order they found curious or outright disagreed with. We may think of this work as producing heterotopia (Foucault 1986): real and localized sites of contestation that engage with and invert the socioeconomic hegemony and its (un)ethical underpinnings. The crew's graffiti was not reproductive of the normative or productive of deviance, not politically left- or right-leaning, complacent or indifferent; rather, it was something different (Cenzatti 2008), something 
reflective. Through graffiti they curated the ongoing story of a public being remade.

\section{CONCLUSION: I am Coryphaeus!}

Aris made this declaration one evening in 2014 as he took off his paintsplattered surgical gloves, tossing them vaguely in the direction of a nearby open dumpster. A still-wet stencil and tag dried a few meters away. Paint fumes and cigarette smoke lingered in the night air. He smiled and lit another cigarette as Thomas folded paper into his backpack, glancing up at the nearby apartment building and down the street. Aris was flying high: it was very late at night and he was with the crew; the stencil was sharp, and its colors popped.

Janet Roitman $(2005,2014)$ suggests that crisis can be the starting point for narration. In Attic drama, the Coryphaeus, or head of the chorus, spoke for the chorus whenever it took part in action. The term is also used to describe the head of a company or group, broadly defined. If democracy is a mode of communication that has been interrupted by the crisis, Aris, in this moment, saw himself as the head of a chorus providing a critical, guiding narrative to an audience struggling to understand the new conversation. This chorus was made up of more than just the crew, but of all crews and writers creating sites of dissent and reflection or, to my interlocutor, alítico graffiti. Of course, his high was also brought on by the thought of what the crew's intervention might preserve.

On January 25, 2015, Greeks voted the Coalition of the Radical Left (SYRIZA) into power. The SYRIZA government survived a divisive referendum on the continued implementation of austerity policy, a split within the party, and fresh elections on September 20 of the same year. For many, these events represented the culmination of five years of social resistance and dissent punctuated by the occupation of public squares in 2011 and actions in solidarity with employees of the public broadcaster, which the previous government had shuttered in an unexpected move in June 2013. My interlocutors did not vote in any of the elections or participate in these or any other actions. Asked why, Tassos explained that voting and protesting were always already "too late." The intervention my consultants sought to make aimed to precede, or rather seed, these actions and events. Alitico graffiti made the suffering endured by everyday subjects legible as abnormal and shared. It bolstered a politics of critical relationality and, ultimately, manifold mobilizations against neoliberal policy. My interlocutors looked hopefully on such changes as the rise of a reconstituted political left and the protests and other forms of resistance not because they bought into the prom- 
ise each communicated, but because these effected, the crew expected, the reinscription of my interlocutors' difference from the mainstream. Tassos explained: "We're looking for a change in the graffiti scene. We'll know something good is happening when people chase us again for writing in their neighborhoods!"

It was now very late and I was sitting with Aris on a bench in a small playground near his apartment. I mentioned, offhand, that I was struck by the ethnographic qualities of the graffiti the crew were writing: they were interpretive, critical, and engaged. Aris simply nodded. I lamented that I could not show any of their current writing in my published work. At this, Aris perked up and

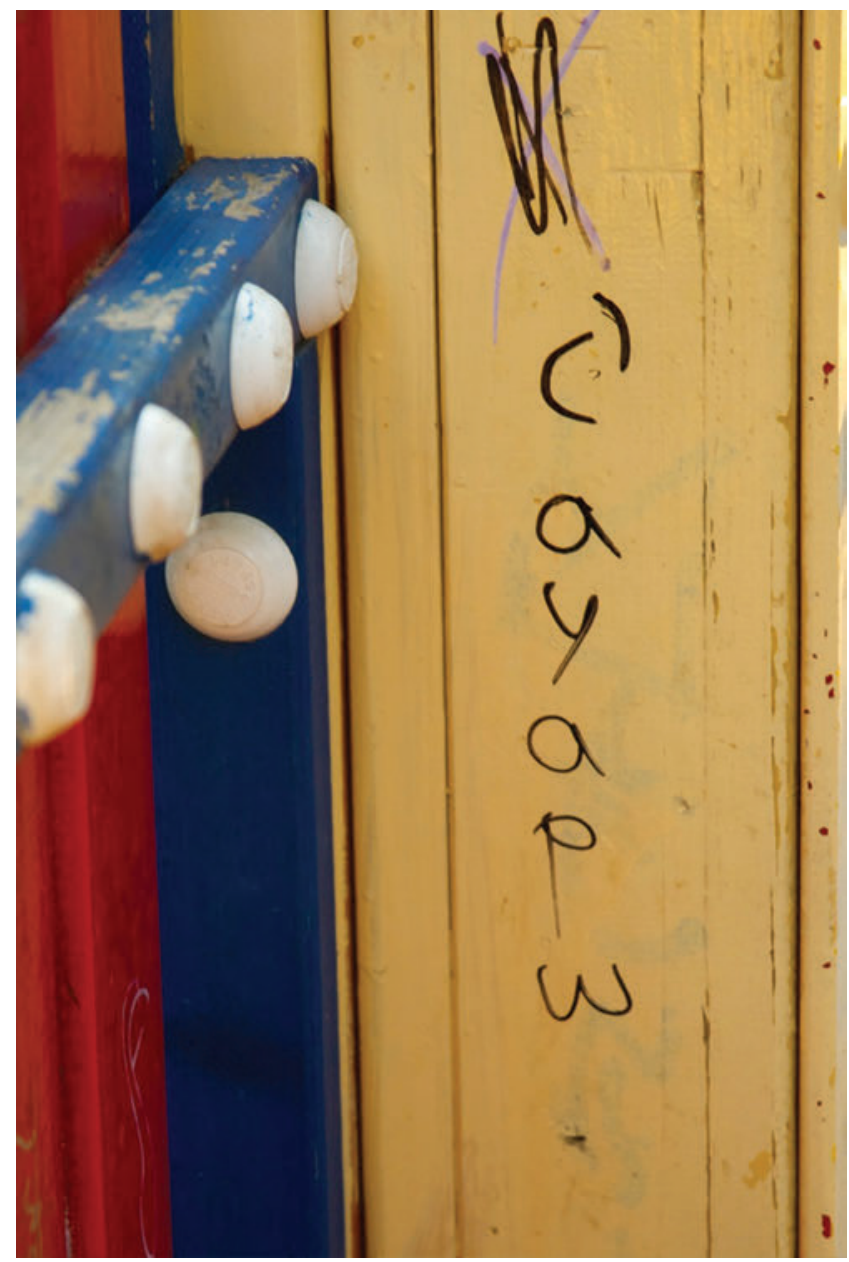

Figure 6. A small tag my interlocutor had been writing in permanent marker on playground structures across Athens. Photo by Othon Alexandrakis. 
pointed to a nearby play structure. We walked over and he gestured toward a word written in permanent marker 'cayap $\omega,{ }^{4}$ "I love you," scribed in an amalgam of French and Greek terms. He explained:

This is mine . . . just mine. I've been writing this everywhere, low, you know, so kids will notice it. My crew doesn't know I've been writing this, nobody does - I mean — it's not a secret, but I just didn't tell anyone. . . . It came to me one day and I started putting it places. It sends a message. It's an important thing to tell kids these days. Come back tomorrow and take a picture. There's no risk with this one, it's just positive, for the future.

We might understand this small intervention in terms of a son speaking to a father blinded and silenced by slow-motion undoing, or an activist shoring up the good in his life by guiding others to understand the dangers in theirs. For Aris, this word - a stand against abandonment in location, form, and meaningheld the potential to start a dialogue with others who might benefit from talking. Whatever connections and reverberations it might cause could only be beneficial.

\section{ABSTRACT}

Based on field research in Athens, Greece, this essay considers graffiti as a mode of political response to the material and symbolic violences of neoliberal governmentality. In 2010, the Greek state declared sovereign debt crisis and began to implement an aggressive austerity program in exchange for economic aid from a troika of international lenders. This resulted in the dismantling of public services, tax increases, salary and pension reductions, layoffs, and, generally, the impoverishment of the middle and lower classes. In this work I consider a crew of three young graffiti writers, both before and during the years of the crisis, as they came to realize a fear of becoming integrated into an economized social mainstream and responded by creating street art intended to bolster critical reasoning among Athenians. I argue that fear of abjection and the experience of being at the social margins served as a stimulus of critical agency, and that the crew's intervention can be considered indirect activism: a mode of resistance whose critical agents attempt to bring about their ambitions and visions by activating other groups to undertake resistance of their own. I show how my interlocutors made political possibility by creating art that lessened the capacity of neoliberal governmentality to manufacture consent, thereby contributing to a thriving ecology of resistance action in Athens. [graffiti; Athens; activism; desubjugation; political subjectivity]

\section{NOTES}

Acknowledgments I am grateful to Aris, Thomas, and Tassos for their trust, tolerance, and for allowing me to collaborate in their graffiti writing. I also want to thank Heath Cabot, 
Ramah McKay, Peter Locke, Salvatore Poier, Elizabeth Anne Davis, and Elizabeth Mertz for their insightful comments on a very early draft of this essay (shared in the context of Heath Cabot's writing workshop for postdoctoral fellows at Princeton University); Anne Meneley and Paul Manning for their helpful comments on a later draft; as well as Cymene Howe, Dominic Boyer, James Faubion, and the anonymous reviewers at Cultural Anthropology. Early versions of this essay were presented to the Greek Studies Group of the Center for European Studies at Harvard University, the Department of Anthropology Speaker Series at McMaster University, and the CASCA plenary "Unsettled Politics and Radical Potential: Figuring the Impulse to Act." I thank Michael Herzfeld, Yannis Ioannides, Tristan Carter, Andrew Gilbert, Daphne Winland, Antonio Sorge, Maya Shapiro, Albert Schrauwers, and Zulfikar Hirji for organizing these events, Neni Panourgiá and Michael Herzfeld for their encouragement and invaluable comments as my discussants, and the participants for their helpful questions and feedback. Research and writing for this essay were supported by the Social Sciences and Humanities Research Council of Canada and by the Seeger Center for Hellenic Studies at Princeton University.

1. This term was made popular by the 2011 film Wasted Youth, directed by Argyris Papadimitropoulos and Jan Vogel.

2. The term heavy cigarettes generally refers to cigarettes laced with marijuana and/or hashish.

3. WD (Wild Drawing) was born in Bali, but has been living and writing in Athens since well before the economic debt crisis. Some local graffiti writers consider him a foreigner, but most regard him as a local.

4. Aris intended the "ca" at the beginning of this word to be pronounced "sa," and the "y" stands in for the Greek gamma. Thus the word reads "s'agapo," or "I love you" in Greek. We might think of this as a one-word tone poem or an aural trope.

\section{REFERENCES}

Ahmed, Sara

2004 The Cultural Politics of Emotion. New York: Routledge.

Allison, Anne

2009 “The Cool Brand: Affective Activism and Japanese Youth.” Theory, Culture \& Society 26, nos. 2-3: 89-111. http://dx.doi.org/10.1177/0263276409103118.

Berardi, Franco "Bifo"

2012 The Uprising: On Poetry and Finance. Los Angeles: Semiotext(e).

Butler, Judith

2002 “What is Critique? An Essay on Foucault's Virtue." In The Political: Readings in Continental Philosophy, edited by David Ingram, 212-27. Oxford: Blackwell.

Butler, Judith, and Athena Athanasiou

2013 Dispossession: The Performative in the Political. Cambridge: Polity.

Cenzatti, Marco

2008 "Heterotopias of Difference." In Heterotopia and the City: Public Space in a Postcivil Society, edited by Michiel Dehaene and Lieven De Cauter, 75-86. New York: Routledge.

Císař, Ondřej, and Martin Koubek

2012 "Include 'Em All?: Culture, Politics and a Local Hardcore/Punk Scene in the Czech Republic.” Poetics 40, no. 1: 1-21. http://dx.doi.org/10.1016/j.

Cowan, Jane K. poetic.2011.12.002.

1990 Dance and the Body Politic in Northern Greece. Princeton, N.J.: Princeton University Press.

Deleuze, Gilles

1997 Essays Critical and Clinical. Translated by Michael A. Greco and Daniel W. Smith. Minneapolis: University of Minnesota Press. 
Deleuze, Gilles, and Félix Guattari

1986 Kafka: Toward a Minor Literature. Translated by Dana Polan. Minneapolis:

Durkheim, Émile University of Minnesota Press.

1951 Suicide: A Study in Sociology. Translated by John A. Spaulding and George Simpson. New York: Free Press. Originally published in 1897.

Feld, Steven, and Keith H. Basso

1996 Senses of Place. Santa Fe, N.M.: School of American Research Press.

Fisher, Mark

2009 Capitalist Realism: Is There No Alternative? Ropley, U.K.: O Books.

Foucault, Michel

1986 "Of Other Spaces." Translated by Jay Miskowiec. Diacritics 16, no. 1: 22-27. http://www.jstor.org/stable/464648.

1997 “What is Critique?" In The Politics of Truth, edited by Sylvère Lotringer, 41-82. Los Angeles: Semiotext(e).

Giovanopoulos, Christos, and Dimitris Dalakoglou

2011 "From Ruptures to Eruptions: A Genealogy of the December 2008 Revolt in Greece." In Revolt and Crisis in Greece: Between a Present Yet to Pass and a Future Still to Come, edited by Dimitris Dalakoglou and Antonis Vradis, 91-114. Graeber, David Oakland, Calif. and London: AK Press and Occupied London.

2009 Direct Action: An Ethnography. Oakland, Calif.: AK Press.

Greenberg, Jessica

2014 After the Revolution: Youth, Democracy, and the Politics of Disappointment in Serbia. Stanford, Calif.: Stanford University Press.

Herzfeld, Michael

1985 The Poetics of Manhood: Contest and Identity in a Cretan Mountain Village. Princeton, N.J.: Princeton University Press.

1987 Anthropology Through the Looking-Glass: Critical Ethnography in the Margins of Europe. New York: Cambridge University Press.

2005 Cultural Intimacy: Social Poetics in the Nation-State. New York: Routledge. Juris, Jeffrey $S$.

2008 Networking Futures: The Movements against Corporate Globalization. Durham, N.C.: Duke University Press.

2012 "Reflections on \#Occupy Everywhere: Social Media, Public Space and Emerging Logics of Aggregation." American Ethnologist 39, no. 2: 259-79. http://dx.doi. Jusionyte, Ieva org/10.1111/j.1548-1425.2012.01362.x.

2013 "On and Off the Record: The Production of Social Legitimacy in an Argentine Border Town.” PoLAR: Political and Legal Anthropology Review 36, no. 2: 231-48.

Kirtsoglou, Elisabeth http://dx.doi.org/10.1111/plar. 12024.

2004 For the Love of Women: Gender, Identity, and Same-Sex Relations in a Greek Provincial Knight, Daniel M. Town. New York: Routledge.

2015 "Wit and Greece's Economic Crisis: Ironic Slogans, Food, and Antiausterity Sentiments." American Ethnologist 42, no. 2: 230-46. http://dx.doi.org/10.

Lewisohn, Cedar 1111 /amet. 12127.

2008 Street Art: The Graffiti Revolution. New York: Abrams.

Mains, Daniel

2007 "Neoliberal Times: Progress, Boredom, and Shame among Young Men in Urban Ethiopia.” American Ethnologist 34, no. 4: 659-73. http://dx.doi.org/10.1525/ ae.2007.34.4.659. 
Massumi, Brian

2010 "The Future Birth of the Affective Fact: The Political Ontology of Threat." In The Affect Theory Reader, edited by Melissa Gregg and Gregory J. Seigworth, 52Mouzelis, Nicos P. 70. Durham, N.C.: Duke University Press.

1978 Modern Greece: Facets of Underdevelopment. New York: Holmes \& Meier.

Navaro-Yashin, Yael

2012 The Make-Believe Space: Affective Geography in a Postwar Polity. Durham, N.C.: Duke University Press.

Ngai, Sianne

2004 Ugly Feelings. Cambridge, Mass.: Harvard University Press.

Panourgiá, Neni

2010 “Stones (Papers, Humans)." Journal of Modern Greek Studies 28, no. 2: 199-224. http://dx.doi.org/10.1353/mgs.2010.0423.

Papataxiarchis, Evthymios

1991 "Friends of the Heart: Male Commensual Solidarity, Gender, and Kinship in Aegean Greece." In Contested Identities: Gender and Kinship in Modern Greece, edited by Peter Loizos and Evthymios Papataxiarchis, 156-79. Princeton, N.J.: Princeton University Press.

Rakopoulos, Theodoros

2014 "Resonance of Solidarity: Meanings of a Local Concept in Anti-Austerity Greece.” Journal of Modern Greek Studies 32, no. 2: 313-37. http://dx.doi.org/ 10.1353/mgs.2014.0040.

Rancière, Jacques

2004 The Politics of Aesthetics: The Distribution of the Sensible. Translated by Gabriel Rockhill. New York: Continuum.

Roitman, Janet L.

2005 Fiscal Disobedience: An Anthropology of Economic Regulation in Central Africa. Princeton, N.J.: Princeton University Press.

2014 Anti-Crisis. Durham, N.C.: Duke University Press.

Sotiropoulos, Dimitri A.

2004 "Formal Weakness and Informal Strength: Civil Society in Contemporary Greece.” Discussion Paper, no. 16. The Hellenic Observatory, London School of Economics.

Stewart, Kathleen

2007 Ordinary Affects. Durham, N.C.: Duke University Press.

Sweeney, John A.

2011 "Burqas in Back Alleys: Street Art, Hijab, and the Reterritorialization of Public Space." Continent 1, no. 4: 253-78. http://continentcontinent.cc/index.php/ continent/article/view/66.

Theodossopoulos, Dimitrios

2013 "Infuriated with the Infuriated? Blaming Tactics and Discontent about the Greek Financial Crisis." Current Anthropology 54, no. 2: 200-21. http://dx.doi.org/ $10.1086 / 669855$. 